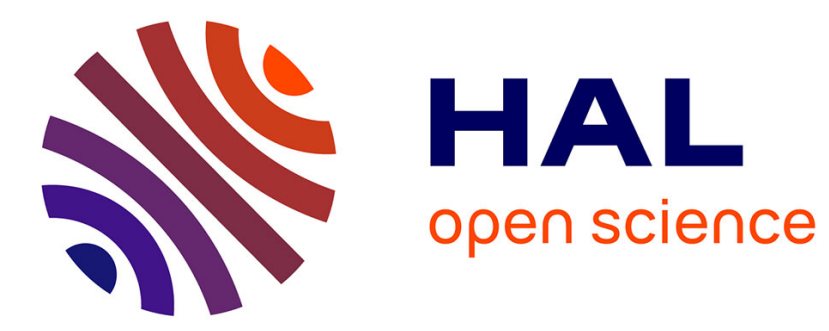

\title{
Export Demand Elasticities and Productivity as Determinants of Growth: Estimates for Mauritius
}

Thomas Ziesemer

\section{To cite this version:}

Thomas Ziesemer. Export Demand Elasticities and Productivity as Determinants of Growth: Estimates for Mauritius. Applied Economics, 2011, pp.1. 10.1080/00036846.2010.537642 . hal-00666679

\section{HAL Id: hal-00666679 \\ https://hal.science/hal-00666679}

Submitted on 6 Feb 2012

HAL is a multi-disciplinary open access archive for the deposit and dissemination of scientific research documents, whether they are published or not. The documents may come from teaching and research institutions in France or abroad, or from public or private research centers.
L'archive ouverte pluridisciplinaire HAL, est destinée au dépôt et à la diffusion de documents scientifiques de niveau recherche, publiés ou non, émanant des établissements d'enseignement et de recherche français ou étrangers, des laboratoires publics ou privés. 


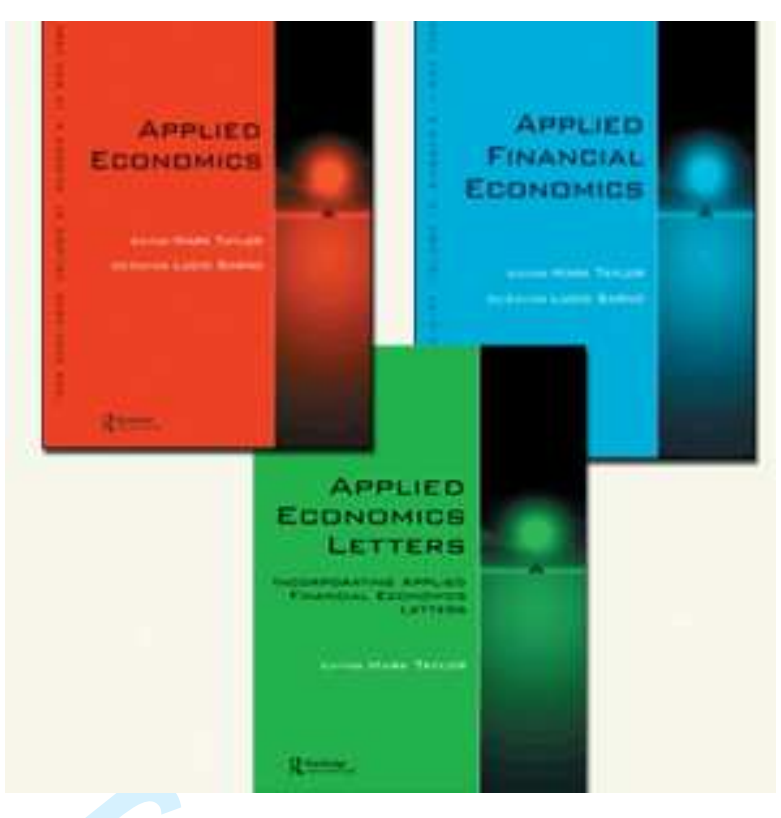

\section{Export Demand Elasticities and Productivity as Determinants of Growth: Estimates for Mauritius}

\begin{tabular}{|r|l|}
\hline Journal: & Applied Economics \\
\hline Manuscript ID: & APE-2009-0512 \\
\hline Journal Selection: & Applied Economics \\
\hline Author: & 14 -Aug-2009 \\
\hline Complete List of Authors: & Ziesemer, Thomas; U Maastricht, Economics \\
\hline & $\begin{array}{l}\text { F43 - Economic Growth of Open Economies < F4 - Macroeconomic } \\
\text { Aspects of International Trade and Finance < F - International } \\
\text { Economics, O11 - Macroeconomic Analyses of Economic } \\
\text { Development < O1 - Economic Development < O - Economic } \\
\text { Development, Technological Change, and Growth, O19 - } \\
\text { International Links to Development; International Organizations }< \\
\text { O1 - Economic Development < O - Economic Development, } \\
\text { Technological Change, and Growth, O41 - One, Two, and } \\
\text { Multisector Growth Models < O4 - Economic Growth and Aggregate } \\
\text { Productivity < O - Economic Development, Technological Change, } \\
\text { and Growth }\end{array}$ \\
\hline Keywords: & $\begin{array}{l}\text { Growth model, trade in capital goods, exports, total factor } \\
\text { productivity }\end{array}$ \\
\hline & \\
\hline
\end{tabular}




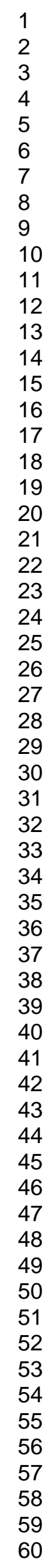

ScholaroNE"

25

26

27

29

30

31

33

34

35

36

37

39

40

41

42

44

45

46

47

48

49

50

52

53

54

55

57

58

59

60 


\title{
Export Demand Elasticities and Productivity as Determinants of Growth: Estimates for Mauritius
}

\author{
Alexis Habiyaremye ${ }^{a}$ and Thomas H.W. Ziesemer ${ }^{b, *}$ \\ ${ }^{\mathrm{a}}$ UNU-MERIT, Maastricht, The Netherlands \\ ${ }^{\mathrm{b}}$ Department of Economics, Maastricht University and UNU-MERIT.
}

Running title: Mauritius’ Export Demand Elasticities, Productivity and Growth

\begin{abstract}
In this paper, we combine the export-led and import-led growth hypotheses in a growth model in which the importation of foreign capital goods and the demand elasticities of own export products explain the growth opportunities and the technical progress of developing countries. This model, based on imported capital goods uses Mauritius' data on capital investment, employment, export partners' growth and terms of trade to estimate price and income elasticities of export demand, total-factor productivity growth and economies of scale. These elasticities are then used to assess how the growth in export partners' income is converted into domestic growth. The implications of the presence of low or high export demand elasticities are discussed by relating them to various strands of trade and growth literature. Based on the results of this estimation, we also calculate steady-state growth rates, engine and handmaiden effects of growth as well as the dynamic steady-state gains from trade for this latecomer export economy. The implications of steady state results are also discussed in the light of the Mauritian employment and growth perspectives.
\end{abstract}

Keywords: Growth model, trade in capital goods, exports, total factor productivity JEL classification code: $\mathrm{O} 11, \mathrm{O} 19, \mathrm{O} 41, \mathrm{~F} 43$

${ }^{*}$ Corresponding author: Thomas H.W. Ziesemer, Department of Economics, Maastricht University, P.O.Box 616, 6200 MD Maastricht, The Netherlands. T.Ziesemer@ maastrichtuniversity.nl. 


\title{
Export Demand Elasticities and Productivity as Determinants of Growth: Estimates for Mauritius
}

\begin{abstract}
In this paper, we combine the export-led and import-led growth hypotheses in a growth model in which the importation of foreign capital goods and the demand elasticities of own export products explain the growth opportunities and the technical progress of developing countries. This model, based on imported capital goods uses Mauritius' data on capital investment, employment, export partners' growth and terms of trade to estimate price and income elasticities of export demand, total-factor productivity growth and economies of scale. These elasticities are then used to assess how the growth in export partners' income is converted into domestic growth. The implications of the presence of low or high export demand elasticities are discussed by relating them to various strands of trade and growth literature. Based on the results of this estimation, we also calculate steady-state growth rates, engine and handmaiden effects of growth as well as the dynamic steady-state gains from trade for this latecomer export economy. The implications of steady state results are also discussed in the light of the Mauritian employment and growth perspectives.
\end{abstract}

\section{Introduction}

The spectacular development of export-oriented East Asian economies in the 1980s and 1990s and the more recent emergence of China as an impressively thriving economy driven by strong export growth rates have once again underscored how exports can act as an important source of growth. However, for a developing country to achieve export-based growth, it must be able to convert export revenues into domestic investments that will generate output growth. In this process, since export revenues depend mainly on foreign demand, income and price elasticities of export demand are important determinant of growth for several reasons:

First, as argued by Khan and Knight (1988), Esfahani (1991) or Wacziarg (2001), the imported inputs invested in domestic production and paid for by exports are the major mechanism explaining the link between exports and growth in the short and the long run. For a developing country that mostly relies on imported capital goods for production technology, if imported capital goods are paid for by export revenues, then income and price elasticities of export demand determine the change in the amount and value of machinery and equipment that can be imported 
for investment. Price and income elasticities determine thus how strongly growth of foreign trade partners is translated into domestic export growth. They have therefore a significant impact on domestic growth and on dynamic gains from trade.

Secondly, they determine the impact of balance of payment constraints on domestic productivity growth when imports are constrained by the foreign exchange gap that impedes developing countries from financing the imports of the needed foreign technologies. Exports of primary commodities and labour-intensive goods could fill the foreign exchange gap and thus provide the needed finance for the importation of the required technologies into the domestic economy. In the presence of a high price-elasticity of export demand, devaluations of currency or depreciations of the real exchange rate increase the value of exports and thus the amount of imports that can be bought from abroad, while they negatively affect the amount of goods that can be imported if export demand is price inelastic (see for example Bahmani-Oskooee and Miteza, 2002). If imports are investment goods, as we will assume in this paper, ${ }^{1}$ devaluations will increase investment when export demand is price elastic and reduce it otherwise (Khan and Knight, 1988; Esfahani, 1991). If these real devaluations or exchange rate depreciations take place for a capital goods importing country, then export demand elasticities are likely to have a significant impact on (future) domestic labour productivity growth through exports of primary commodities or labour-intensive goods and technology imports.

Thirdly, export demand elasticities determine the speed and intensity of self-curtailment of export booms caused by technological progress. Indeed, if technical progress leads to lower terms of trade, this effect is translated into changes in the growth rates of exports and investments. Therefore, if booming exports drive up the terms of trade, price elasticities also determine the magnitude of the self curtailment of the boom by boosting export prices and thereby slowing down

\footnotetext{
${ }^{1}$ Khan and Knight (1988) and Esfahani (1991) also assume all imports to be investment inputs.
} 
the demand for exports. For all these reasons, this paper presents a growth model that enables to simultaneously estimate the price and income elasticities of export demand as well as the productivity growth and scale economies for a developing country.

This model is developed from a slightly modified version of a two-gap growth model with imported inputs, introduced by Bardhan and Lewis (1970) and is used here to estimate and analyse the income and price elasticities of export demand for Mauritius, a country reported among the fastest growing economies in the world, but whose exports remain dominated only by textile and sugar products, therefore vulnerable to demand shifts in any of these products. The model also yields estimates for the total factor productivity growth and scale effects. This paper contributes thereby to some strands of literature dealing with growth effects of the trade between developing countries and technologically advanced economies:

First, in this model, the importation of capital goods and the elasticities of export demand provide explanations for the link between foreign income and domestic growth rates of developing countries. This paper contributes thus to further explaining the relationship between labour intensive goods and primary commodity export, capital goods import and growth in developing countries. The literature on the trade-growth nexus has followed two main hypotheses to explain the impact of trade on the growth of the trading economy: the export-led growth hypothesis and the import-led growth hypothesis. The export-led growth hypothesis (ELGH) postulates that export expansion is one of the main determinants of growth. The ELGH links to the endogenous growth theories and points mainly to the access to inputs and global markets and the resulting efficient reallocation of existing resources, economies of scale and various labour training effects as a 
source of growth (see e.g. Bhagwati, 1978 or Balassa, 1980). According to its advocates, exports can act as an engine of growth". ${ }^{2}$

Second, as stressed by Thangavelu and Rajaguru (2004), there are stronger theoretical and empirical reasons to believe that in open economies, import-led growth rather than export-led growth could be the main driver of productivity increase in developing countries. In contrast to the ELGH that emphasizes market access, the import-led growth hypothesis stresses the importance of the modernization process and the acquisition of advanced technologies through the import of sophisticated equipment and machineries (Marwah and Klein, 1998; Keller, 2002; Navaretti and Soloaga, 2002). Access to foreign capital goods boosts productivity growth, as underlined by the new developments in the theory of international trade, broadly through demonstration effects of products containing new technological knowledge. International trade in capital goods that embody new technologies is thus of utmost importance in spreading the benefits of technological advance to developing countries (Mazumdar, 1999; Eaton and Kortum, 2001; Caselli and Wilson, 2004).

Third, our estimates enable us to calculate the steady-state part of the dynamic gains from trade conditional on some assumptions about future employment growth. As the growth model presented in this paper emphasises the growth advantages derived from technology embodied in imported capital goods, paid for by export revenues, our results show that the larger the income elasticity of export demand, the larger the amount of capital goods that can be imported from abroad and therefore the larger the growth rate of the domestic economy in this model. Our growth model is

\footnotetext{
${ }^{2}$ See Medina-Smith (2001) for an extensive review of the literature dealing with export-led growth hypothesis. Criticism on this hypothesis include the difficulty of measurement of its indicators (Rodrigues and Rodrik, 1999) and the direction of causality as pointed out by a.o Bernard and Jensen (1999) who argue that export growth might be the result of growth rather than its cause.
} 
thus also a contribution to the literature on the role of imported technologies in the growth of the importing country. By this growth model based on imported inputs paid for by export revenue, we bring together both export-led and import-led growth hypotheses and reconcile the corresponding theories as two sides of the same medal.

Finally, the literature on balance of payments constrained growth is closely linked to that of twogap models. In these models, the standard approach has been to solve the balance of payments for the relative growth rate of the country in question and the trade partners by assuming that terms of trade are constant or have no impact3. Even in models that made terms of trade endogenous such as Fagerberg (1988) or Verspagen (1993), demand has no direct effect on the terms of trade. By adding the demand side to that literature, we are able to estimate not only the effects of technological change, but also those of demand shifts on the evolution of terms of trade.

The remaining parts of the paper are organised as follows. The next section outlines the model and its assumptions and presents its solution in the transitional path and steady state. Section 3 presents Mauritian data that will be used to estimate the model and its price and income elasticities of demand as well as productivity growth with the general method of moments (GMM) estimator in section 4. In particular, we estimate the elasticities from the equation as derived from the model with linear estimators, thus maintaining theory and empirical analysis as closely linked as possible. The results of this estimation are used to calculate the main steady state components of the growth dynamics, namely the engine and the handmaiden source of growth, conditional on assumptions about employment growth. Dynamic gains from trade are also calculated as the difference between the resulting growth rate and the corresponding growth as predicted by the habitual Solow model with the same parameters. 4 The final section discusses the various findings in the light of the

\footnotetext{
${ }^{3}$ See e.g. Bertola et al. (2002) on this literature.

${ }^{4}$ Similar work for Brazil has been done by Mutz and Ziesemer (2008).
} 
existing literature on trade and growth, and derives some concluding implications for Mauritius' diversification strategy.

\section{The Imported Inputs Growth Model}

The model outlined in this section is based on a modified version of a two-gap growth model with imported factor inputs, introduced first by Bardhan and Lewis (1970) and modified by Ziesemer (1995) in order to make effects of technical change and income elasticities explicit. That model emphasizes the insights that for developing countries, imported inputs paid for by export revenues are the major mechanism of growth in the relation between export and growth, as put forward and empirically supported by Khan and Knight (1988).

Since the lack of technology is widely seen as the main obstacle to economic growth in most developing countries, capital goods import can be viewed here as a structured way of acquiring the relevant technologies that help countries deal with the constraints of existing (sometimes archaic) production methods as well as building a long-term dynamic comparative advantage. This model is modified into a full-fledged growth model of imported inputs that reflects the situation of Mauritius with some simplifying assumptions:

1. Imported capital goods are the only source of investment ${ }^{5}$;

2. All capital goods are paid for by the revenue from export;

3. Import of consumption goods from export revenue is fairly negligible;

4. There is no external debt to finance imports and trade is balanced.

\footnotetext{
${ }^{5}$ Since most of sophisticated machineries are produced in advanced countries, this assumption holds for a majority of developing countries for diverse types of machinery and investment equipment.
} 
In this model, the importation of capital goods and the elasticity of export demand contribute to explaining the growth behaviour of developing countries. The simplifying assumption made of no domestic production of capital goods is a fair approximation for the reality of many developing countries and is thus suited even to the analysis of the Mauritian case. In order to deal with the question whether imports of capital goods and the magnitude of export demand elasticities could account for the relative speed of growth in comparison to the Solow (1956) growth model, the current model assumes flexible wages and exogenous employment and uses Cobb-Douglas production function with exogenous technical progress:

$$
Y=e^{b t} A K^{\beta} L^{\alpha} U, 0<\alpha, \beta<1 ; \alpha+\beta \geq 1(\leq 1)
$$

$Y$ denotes output, $K$ capital, $L$ labour, $b$ the rate of technological progress, ' $A$ ' is a time independent constant, $U$ a stochastic term and $\alpha$ and $\beta$ the elasticities of production of labour and capital respectively. The model allows for increasing, decreasing and constant returns to scale. ${ }^{6}$ Labour is assumed to grow at rate $\varepsilon$, which is determined exogenously:

$$
L(t)=L(0) e^{\varepsilon t}, \hat{L}=\varepsilon
$$

$\hat{L}$ denotes the proportional growth rate of labour input $L$.

Some of the fundamental obstacles for developing economies are due to the fluctuation of the already limited export demand and the resulting foreign exchange constraint that limits the

\footnotetext{
${ }^{6}$ We make no assumptions on market structure. Under decreasing and constant returns to scale we could have perfect competition and the marginal productivity conditions would be separable and determine the factor prices. Under increasing returns we could assume that they stem from externalities at rate $\beta-(1-\alpha)$ and assume perfect competition again. Alternatively, we could introduce imperfect competition with the implication that the Lagrange-multiplier from cost-minimization equal to marginal cost would goods prices divided by a mark-up factor with value smaller than unity. With separable dynamics of factor inputs this would reduce real factor prices. Without having an estimate it is not clear though which case we have. Our estimated outcome will be very close to constant returns to scale.
} 
capacity to import capital goods for investment. Importing less luxury consumption goods may be helpful in reducing the foreign exchange gap, but cannot be a solution by itself. In this model, we therefore assume that no consumption items are imported so that all export revenue is used to import capital goods. However, problems related to the terms of trade or export growth may occur despite the absence of imports of consumption goods. Producing capital goods domestically is also not a viable solution, because the cost of producing capital equipment could be prohibitively high in most developing countries as can be concluded from substantial empirical evidence showing developed countries' comparative advantage in producing capital goods ${ }^{7}$. Mazumdar (1999) has therefore suggested that for developing countries, producing capital goods rather than importing them is misallocation of resources since they are at a comparative disadvantage in such a production. In this model, we consequently assume that no capital goods are produced domestically and all capital goods invested in developing countries must thus be imported (see footnote 3$)$.

$M=\dot{K}$

$\dot{K}$ denotes the derivative of $K$ with respect to time and $M$ represents imports. For reasons of simplicity, we assume capital goods to be the only imports so that all export revenues are used to finance capital investments. This assumption is not binding since the model still holds if we assume capital goods import to be only a large share of total import; the requirement of financing import by export revenue stems from the trade-balance equilibrium. Investments are therefore limited by exports, denoted $X$, which are expressed in terms of the imported capital goods. The

\footnotetext{
${ }^{7}$ See for example Lee (1995) or Mazumdar (1999) for an overview
} 
growth of capital goods in the domestic economy is thus constrained by the export revenue and can be written as:

$$
\hat{K}=\frac{\dot{K}}{K}=p \frac{X}{K}-\delta, \hat{\hat{K}}=\hat{p}+\hat{X}-\hat{K} ; \hat{\hat{K}} \equiv d(\log (\hat{K}+\delta)) / d t
$$

where $\hat{K}$ denotes the proportional growth rate of the capital stock $K$, while $X$ represents the exports and $\mathrm{p}$ represents the terms of trade, defined as the price of domestic goods in terms of imported capital goods. Here again, a hat on a variable means a proportional growth rate while a dot on a variable represents change with respect to time. The balance of payment equilibrium condition means that investments need to be paid for by domestic savings, which must equal exports measured in terms of imported capital goods. The savings rate $s$ is assumed to be a constant proportion of output and depreciation $\delta K$ is a constant portion of the existing capital stock:

$$
\hat{K}=\frac{\dot{K}}{K}=s p \frac{Y}{K}-\delta, \hat{\hat{K}}=\hat{p}+\hat{Y}-\hat{K}
$$

The value of export revenue determines thus the amount of capital goods that can be imported and invested in the domestic economy. Exports $X$ are in turn assumed to depend on the trade partners' income, $Z$, and on the terms of trade $p$. For the sake of simplicity, a log-linear export function with a constant $B$ and a stochastic term $V$ is used:

$$
X=B Z^{\rho} p^{\eta} V, \rho>0, \eta<0
$$


Here $\rho$ denotes the income elasticity and $\eta$ represents the (negative) price elasticity of export demand. Together, these six equations explain the six variables $Y, L, M, p, K$, and $X .^{8}$ Inserting the functions for exports and output, (6) and (1), into the export and saving constraints for investment, (4) and (5), respectively, and taking into account the depreciation rate $\delta$ on the left hand side and then taking natural logarithms, denoted $l n$, yields:

$$
\begin{aligned}
& \ln (\hat{K}+\delta)=\ln B+\rho \ln Z+(1+\eta) \ln p-\ln K+\ln V \\
& \ln (\hat{K}+\delta)=\ln s+\ln p+b t+\ln A+(\beta-1) \ln K+\alpha \ln L+\ln U
\end{aligned}
$$

In addition, we assume that firms know $L$ and $K$ (from the end of previous period) with certainty and produce after $U$ has become known. Households then decide to save a fraction $s$ of their income $Y$ and this determines gross investment. When the $V$-term in the export function is known, the terms of trade $p$ can adjust to determine external trade balance equilibrium. All rigidities and the implied consequences for the future are assumed to be absent for the sake of simplicity. In particular, downward adjustment of $K$ is assumed to be lower than the depreciation rate and therefore of no relevance here. In this model, the output per worker in units of domestic goods is considered a rough indicator of welfare. The driving forces behind the per worker output growth are the rate of technical progress $b$ and the growth rate of the capital-labour ratio, which is denoted by $k$.

$$
\hat{y}=b+\beta \hat{k}+(\alpha+\beta-1) \hat{L}+\ln U
$$

\footnotetext{
${ }^{8}$ Note that according to basic knowledge in differential and difference equation theory $K$ and its change are counted as one variable.
} 
The last term corrects for scale economies. Since the rate of technical progress is given, the remaining question is whether a low income elasticity of export demand hinders rapid growth of the capital-labour ratio by restricting the importation of capital goods. The growth rates for the long-term equilibrium growth path are of crucial interest in this respect. Solving equations (4') and $\left(5^{\prime}\right)$ for the natural logarithms of the terms of trade and the left hand side variable yields:

$$
\begin{aligned}
& \ln (\hat{K}+\delta)=\frac{-\ln B}{\eta}+\ln A \frac{(\eta+1)}{\eta}+\frac{\eta+1}{\eta} \ln s+\frac{b(\eta+1)}{\eta} t+\frac{\beta \eta+\beta-\eta}{\eta} \ln K+\frac{\alpha(\eta+1)}{\eta} \ln L+\frac{-\rho}{\eta} \ln Z+\frac{(\eta+1)}{\eta} \ln U-\frac{1}{\eta} \ln V \\
& \ln p=\frac{\ln A-\ln B}{\eta}+\frac{1}{\eta} \ln s+\frac{b}{\eta} t+\frac{\beta}{\eta} \ln K+\frac{\alpha}{\eta} \ln L-\frac{\rho}{\eta} \ln Z+\frac{1}{\eta}(\ln U-\ln V)
\end{aligned}
$$

In order to solve for the expected value of the steady state growth of capital, the next step is to take the derivative with respect to time of these two equations, set both sides equal to zero and assume a constant saving rate in the steady state. The expected value of equation (8) is a differential equation in $K$ with a negative slope. $K$ has an impact on equation (9) but $\ln p$ has none on (8). Thus, dropping $\ln U$ and $\ln V$ because their expected value is zero, the steady-state growth rate can be written as follows:

$$
\hat{k}=\frac{\rho \hat{Z}-\varepsilon-(1+\eta)[(\alpha+\beta-1) \varepsilon+b]}{-\eta(1-\beta)+\beta}
$$

If we now insert this solution into the equation determining the change in the terms of trade and into equation (7), we obtain the following solutions for the terms of trade $p$ and income per capita $y$, respectively: 


$$
\begin{gathered}
\hat{p}=\frac{(1-\beta)(\rho \hat{Z}-\varepsilon)-(\alpha+\beta-1) \varepsilon-b}{-\eta(1-\beta)+\beta} \\
\hat{y}=\frac{\beta(\rho \hat{Z}-\varepsilon)-\eta[(\alpha+\beta-1) \varepsilon+b]}{-\eta(1-\beta)+\beta}
\end{gathered}
$$

The numerators of equations (10), (11) and (12) consist of three terms, the first of which reflects the engine of growth part from the export demand function: the growth rate of trade partners' income multiplied by the income elasticity of export demand minus the labour growth rate. The product of trade partners' income and income elasticity is the driving force on the demand side. Hence, here the causality runs from exports (financing the import of capital investment) to growth. The second part captures the view that technical progress leads to an increase in exports through decreased prices if exports are price elastic. It represents the handmaiden part of growth dynamics (see also Kravis 1970). As a consequence, the causality of this last effect runs from growth to exports. This model contains both parts, but the handmaiden part drops out if a country has no technical progress. The third part is only relevant in the case of non-constant returns to scale. With increasing or decreasing returns to scale, we have an additional cost reduction or increase which drops out if $(\alpha+\beta=1)$ in equations (10) through (12).

The direct effect of technical progress and returns to scale is to decrease production costs and to reduce the terms of trade as can be observed in equation (11). One would then ask whether this will cause exports and investments to rise or to fall. If exports are price-elastic, exports and investments will increase, and so will the capital-labour ratio as suggested by equation (10). Conversely, if exports are price-inelastic, technical progress will have a negative impact on the growth rate of the capital-labour ratio. As for the growth rate of per capita income, it is obvious 
that technical progress has not only a direct, but also an indirect effect on this variable. The indirect effect is due to changes in the capital-labour ratio (capital deepening) induced by technical progress. For a primary commodity exporting developing country, this question has relevance mainly when the technological progress takes place in this export sector.

The implications of these elasticity values for the steady-state growth can be interpreted from the relationships between output growth, income elasticity of demand and the accumulation of capital goods as plotted in Figure 1 for alternative values for the price elasticity. Under the assumptions of constant returns to scale and $\hat{Z}=\varepsilon+b /(1-\beta)$, the slope in Figure 1 increases with the price elasticity of exports. The slope will be less steep the more price-elastic the exports are. For income elasticities higher than one, the economy grows at a faster rate than that predicted by the Solow model. These conclusions however do not hold for the special case of a price elasticity of minus infinity, since this is the small country case of a price taker, which yields the results of the Solow growth model. For all other values of the price elasticities this model is neither a small country case in terms of the standard textbook definition of having no impact on the terms of trade, nor is it a special case of the two country model. We use it as an open economy growth model. ${ }^{9}$

\section{INSERT FIGURE 1 OVER HERE}

To explain the interplay between the growth rate of the terms of trade and the income elasticity of export demand, figure 2 plots this relationship also for alternative values of export demand price elasticities. The less price-elastic the exports, the steeper the slope and the more negative the

\footnotetext{
${ }^{9}$ It could easily be extended to a multi-country growth model. If we give every variable and parameter a country index $i$ - with the exception of time index $t$ and world income $Z$ of course -, then we only have to add the equation $Z=$ $\sum_{i} y_{i} L_{i}$. If the share of Mauritius' GDP in world income is very small, $Z$ is essentially exogenous. Then also there is no reason why $Z, k$ and $y$ should have the same growth rate (up to population growth rates). Our formulas show explicitly that this is not the case, because $Z$ drives the demand side and technical change the supply side. If these two forces do not grow at the same speed, terms of trade change, unless one assumes a one good world where they are constant by construct. Another extension would be the reintroduction of domestic capital goods as in Bardhan/Lewis (1970) where the corresponding Cobb-Douglas parameter would be zero for countries with no capital goods production. But this is not relevant for Mauritius.
} 
vertical intercept. For income elasticities smaller than one, the growth rate of the terms of trade fall and real wages grow at a lower rate than in the Solow model. For income elasticities higher than one, terms of trade do not deteriorate and real income grows at a higher rate than in the Solow model if the technological progress and scale economies do not shift the supply (i.e. if employment growth remains moderate). There is thus a close relationship between the movement in terms of trade and the real domestic output growth. The driving force behind both of them is the income elasticity of export demand. Its effects are only partly counterbalanced by a relatively high price elasticity of export demand. As a general rule, a high price elasticity will thus weaken the impact of the income elasticity of export demand on the evolution of real income and the terms of trade.

The estimated elasticities also mean that technological change increase labour productivity at an estimated annual rate of about $2 \%$ as a result of the technological content of imported capital goods and a human capital accumulation. This positive rate of technical change is likely to contribute to lowering the terms of trade and increasing the domestic real wage rate. It works thus in opposite direction compared to high income elasticity of demand. The price and income elasticities of export demand are crucial determinants for a developing country's growth prospects.

\section{INSERT FIGURE 2 OVER HERE}

To summarise, technical progress and increasing returns to scale have a negative impact on the terms of trade while they influence per capita income positively. The higher the income elasticity, the higher the growth of export demand for any growth rate of trade partners income and the higher the growth rate of capital imports in equation (10). The latter aspect causes income in equation (12) to grow at a higher rate and the growth rate of the terms of trade is driven up as well. A higher growth rate of income in the trade partner countries will lead to an increase in exports. Yet, the critical point is whether the change in income multiplied by the income elasticity of export 
demand -representing capital investment growth rate- exceeds the labour growth rate $\varepsilon$. This difference governs the growth rate of the capital-labour ratio in equation (10). In the case of constant returns to scale, if the income elasticity of export demand is low and the labour force growth rate is high, the effect on the growth rates on the terms of trade, the capital-labour ratio, and income per capita will be negative in the absence of technical progress.

In conclusion, the terms of trade will fall on condition that the rate of technical progress and scale economies is not exceeded by a large difference between the export growth rate and the labour growth rate in equation (12). The growth rates of the capital-labour ratio and income per capita may be negative because of low price- and income elasticities. On the other hand, with a high income elasticity of export demand, a low labour force growth rate and a high rate of technical change in the presence of positive scale economies, high steady-state growth rates are possible as well. With respect to income elasticity and trade partners' income growth, the terms of trade are an indicator of economic development, because they boost both per capita income and the capital accumulation if exports are price elastic.

\section{Mauritius' exports, terms of trade and capital accumulation data}

\subsection{Economic overview}

In this section we present a brief overview of the Mauritian economy and the data used to empirically estimate the growth model for Mauritius. The Mauritian economy has been expanding at a sustained rate for almost four decades as a result of continuous accumulation of physical and human capital. Gross domestic fixed capital formation as a percentage of GDP has been strong, fluctuating at around 25\% between 1990 and 2000 and stabilising to $22.5 \%$ between 2001 and 
2005. This rate of investment compares favourably with that of other developing and developed countries.

Mauritius is one of the few sub-Saharan African countries that managed to enter the market for manufacturing export and it is exceptional in that it has transformed itself from a monocrop agrarian economy into an impressive industrial performer. Its transformation from a sugar dependent economy into one of the leading export manufacturers in Africa, owing mainly to the Export Processing Zone (EPZ)-based trade policies of early 1970s, has set standards for other African countries to emulate. With almost $75 \%$ of its exports consisting of manufactures today, it is the uncontested SSA leader in making the transition from dependence on primary commodities to diversifying productive activities (Wingnaraja et al., 2004).

These achievements are even more remarkable when one takes into account the difficult initial conditions. Back in the late 1960, when it gained independence from Britain, it was a poor developing nation with a dualistic economy based primarily on a highly productive sugar export sector and a poorly performing subsistence agriculture sector. Moreover, it had only negligible industrial and managerial experience to rely on, while investment capital was lacking as a result of inexistent financial institutions and intermediaries. Like any other typical poor developing country back then, it started from economic dependence on a single primary commodity, a very small domestic market with low purchasing power and remote from developed western markets, while also lacking raw material and other natural resources (Wingnaraja et al., 2004). This remarkable transformational achievement has also been translated into a more equitable income distribution, increased human capital stocks and life expectancy, lower infant mortality, and a modern infrastructure (Subramanian and Roy, 2003). Sugarcane is however still grown on about $90 \%$ of the cultivated land area and still accounts for $25 \%$ of export earnings (World Factbook, 2006). 
Currently, Mauritius has one of the strongest economies in Africa; 2004 GDP at market prices was estimated at USD 6 billion and its PPP adjusted per capita income reached USD 13,500 in 2006 (World Factbook, 2006). Over the past two decades, real output growth averaged just below $6 \%$ per year, leading to a more than doubling of per capita income and a marked improvement in social indicators. Economic growth was first driven by sugar, then by textiles and tourism, and more recently by financial services (particularly offshore companies). The information and communications technology (ICT) sector is now emerging as the fifth pillar of the economy, following massive investment by government in the last three years in related infrastructure and training (the newly built Ebene Cyber City is one example). The growth model we present here captures these aspects of improved public infrastructure, increase in human capital stock and the corresponding productivity growth effects of sectoral shift in its estimation of total factor productivity (TFP) growth.

\subsection{Data and data sources}

After the overview of the Mauritian economic situation and aspirations, we now present the data used to estimate the price and income elasticities needed for carrying out an empirical estimation of its growth potential. The equations to be estimated below are (8) and (9). These equations hold for both the steady state and the transition path and are thus particularly interesting. These equations will be estimated as a simultaneous system. Once the system is estimated, all parameters can be identified and be used to calculate the various elasticities needed to analyze the imported input model.

In order to estimate the equations, time series data for the savings or investment/GDP ratio, capital, trade partners' income and employment are required. The data for gross fixed capital formation as percentage of GDP are taken from the World Development Indicators and represent 
investment. For the investment base year, we use gross fixed capital formation as of 1980, because the data series prior to that period show an excessive amount of missing observations and are therefore of little use for the analysis. The values of investment are used instead of the savings ratio in order to account for the portion of investments that is financed by foreign capital, which is not incorporated in this model. The data for capital are constructed by cumulating Gross Domestic Fixed Capital Formation (GDFCF) after subtraction of the data for depreciation. To estimate the initial value of capital stock at the beginning of the year 1980, we first compute the capital growth rate derived from the growth of output and the growth of labour employment for which we have data, assuming constant returns to scale Cobb-Douglass production function with conventional factor shares and using a TFP growth of $0.6 \%$, such as estimated by Subramanian and Roy (2003) for Mauritius. ${ }^{10}$ Writing output $Y=A K^{\alpha} L^{\beta}$, we can take the natural logarithms and obtain $\ln Y=\ln (A)+\alpha^{*} \ln (K)+\beta^{*} \ln (L)$. By taking the differences $d \ln (Y)=d \ln (A)+\alpha^{*} d \ln (K)+\beta * d \ln (L)$ and assuming constant returns to scale(i.e. $\alpha+\beta=1)$, we can equate $d \ln (K)$ to $(d \ln (Y)-d \ln (A)$ $\left.\beta^{*} d \ln (L)\right) /(1-\beta)$ : The growth rate of GDP was $4.56 \%$ for the year $1980 / 1981$ according to the World Development Indicators. Using the conventional labour and capital shares (respectively 2/3 and 1/3), a corresponding average labour growth of 3.34\% and Subramanian and Roy's (2003) average estimate for Mauritian TFP growth at the beginning of the period, the growth rate of capital was estimated to be $4.91 \%$. Once the capital growth rate has been estimated, we then use the data for depreciation (computed from the WDI ratios of fixed capital consumption as a percentage of GNI) and investment (GDFCF) to estimate the initial value of $K$ as follows:

\footnotetext{
${ }^{10}$ Using the growth accounting approach, Subramanian and Roy (2003) estimated Mauritian TFP growth to average $0.6 \%$ for the period 1982-1990.
} 
$K_{0}=\left(G D F C F_{1}\right.$ Depreciation $\left._{1}\right) / \Delta \ln (K)^{11}$

As Mauritius has been sourcing its capital import from various parts of the world, we chose to use the value in constant local currency units (Mauritian rupee MUR) for the capital stock, deflated by the capital investment index for Mauritius (CSO data) and corrected for the change in terms of trade. With the capital stock constructed in this way, we can determine growth rates as log differences and add the rate of depreciation (determined by the depreciation amount relative to the capital stock at the beginning of each year) to get the dependent variable of equation (8).

The employment data were computed by using the Heston-Summers-Aten PWT6.2 dataset on GDP per worker and GDP per capita and the WDI data on population and represent full-time equivalent of formal employment. We also include the data for 2005 and 2006 computed from the WDI labour force and the Bank of Mauritius unemployment rate, despite the adverse employment impact of the phasing out the MFA in 2005, which has seriously affected Mauritian textile export and employment (see Lal and Peedoly, 2007). By dividing GDP per capita by GDP per worker, we determined the rate of worker per population, which, when multiplied by total population, yields the total employment head count in the country. However, as recalled by Lamusse (1980), the labour in the sugar cane plantations has been characterised by a strong seasonality and part-time employment. We therefore applied a correction factor to account for this by estimating the fulltime equivalent factor of around $70 \%$ in the years 1980-through halfway the 1990s (when sugar was still dominant in the economy), which we increased to $90 \%$ for the years afterwards (when the clothing and apparel industry had taken over as the major export product) to reflect the larger intensity of employment and labour shortage in that period (see also Subramanian and Roy, 2003).

\footnotetext{
11 The initial capital increase $\Delta \ln K=\ln \left(K_{1}\right)-\ln \left(K_{0}\right)$ is approximately $\left(K_{1}-K_{0}\right) / K_{0}$. Since $K_{1}$ is obtained by adding to the initial capital stock $K_{0}$ the capital formation in the first period and Subtracting the corresponding depreciation, $K_{1}$ can be written as: $K_{1}=K_{0}+G D F C F_{1}-$ Depreciation $_{1}$ so that $\Delta \ln (K)=\left(K_{0}+G D F C F_{1}-\right.$ Depreciation $\left._{1}-K_{0}\right) / K_{0}$. By a simple arithmetic manipulation, we obtain $\triangle \ln K^{*} K_{0}=\left(G D F C F 1-D_{\text {epreciation }}\right)$. From here, the initial capital stock can be derived as $K_{0}=\left(G D F C F_{1}\right.$ Depreciation $\left._{1}\right) / \Delta \ln (K)$.
} 
The time series starts in 1980 and covers the period through 2006. Trade partners' income is taken to be the trade-share weighted average income (in constant international dollars at 2000 prices) of the European Union, the US and the United Arab Emirates, the three major export markets for Mauritian products. The terms of trade were calculated as 'exports as capacity to import' divided by 'exports of goods and services', both in terms of constant 1998 local currency units.

\section{Estimation methods and results}

\subsection{Econometric method}

Before discussing the methods, we check whether the time series follow unit root processes and determine the order of integration of the variables. Econometric methods have indeed been developed traditionally either for stationary variables and more recently for variables being integrated of order one, $I(1)$. Our testing for unit roots will suffer from the fact that these tests have been designed for a large number of observations over long time periods, whereas we deal with only a few observations over only 20 year period. Hence, the tests results that we obtain here have only limited explanatory power. However, while bearing in mind their low explanatory power for the case at hand with shorter series, we nonetheless note that our augmented Dickey-Fuller (ADF) test results fail to reject the unit root hypothesis for the variables $\ln (Z)$ and $\ln (L)$. The presence of unit root in these variables would mean that they are not covariance stationary, thus that they appear to be a random walk with a stochastic drift (Greene, 2003: p780-781). In that case, the autocorrelation function of this random walk is persistent as the sample time span increases, and standard inferences based on least squares and the familiar test statistics would no longer be valid (Baltagi, 2008: p. 361). 
In the case of multivariate time series where only some of the independent variables seem to display unit root processes, Verbeek (2004: p. 314) suggests that adding lagged regressors of variables that seem not to be stationary would suffice to render OLS estimates consistent. However, it is also important to recall that unit root tests suffer from the fact that they often are unable to discriminate between unit rood processes and borderline stationary processes (Baltagi, 2008: p.362). In the data of our estimated regressions, $\ln (Z)$ has obviously a trend but may not have a unit root. $\operatorname{Ln}(L)$ seems to have a unit root, which can partly be attributed to the fact that it was constructed from various data series. However, it is not a random variable but rather a constructed series to which unit root theory does not apply. In any case, our estimated regressions do not indicate any persistent autocorrelation.

Furthermore, the system to be estimated has three important aspects to be taken into account in choosing the estimation method. The first one has to do with constraints on the coefficients, which imply a non-linear estimation problem. We have one constraint per regressor in equations (8) and (9), except for the intercept and the trade partners' income variable, which has the same coefficient in both equations. The second aspect refers to the random terms from the production function and the export function in both equations of the system and has as a consequence that the residuals of the two equations will not be independent. These two properties together suggest using the seemingly unrelated regression (SUR) method. The seemingly unrelated regression method, also known as the multivariate regression, or Zellner's method, estimates the parameters of the system, accounting for heteroscedasticity and contemporaneous correlation in the errors across equations. The third aspect comes from the differential equation properties of equation (8) which imply residuals have an impact on all future variables of capital. It also implies that the regressor in the first equation is not exogenous although it is predetermined (see also Davidson and Mackinnon, 
2004). Moreover, the saving rate might also vary with the accumulated capital, rendering it not strictly exogenous.

As this would render OLS estimates biased, we use the generalized method of moments (GMM) with heteroscedasticity and autocorrelation correction (HAC) of the coefficient standard deviations, in which we include the lagged saving rates and lagged variables of capital as instruments. GMM estimation is based upon the assumption that the disturbances in the equations are uncorrelated with a set of instrumental variables and is thus a robust estimation method in that it does not require information of the exact distribution of the disturbances. Table 1 reports the estimates of the various estimation methods and allows comparing the OLS results to the SUR and GMM estimates. The OLS estimates produce elasticity coefficients that yield an unlikely low measure of returns to scale, while the SUR results yield an unlikely high capital product elasticity and therefore a too high measure of returns to scale. As noted above, these estimates are thus biased and inconsistent; they cannot thus be relied upon.

The GMM estimation of the system as specified in equation 8 and 9 yields coefficients that are significant but also manifestly biased and inconsistent as a result of serial correlation in both equations ( $D W=0.77$ in the first equation and $D W=0.64$ in the second). To reduce this problem, we add the lagged dependent variables to the system of equations and also add their lagged values as instruments (See Davidson and MacKinnon, 2004). The resulting GMM-HAC estimates with lagged dependent variables in the two equations are reported under regression no 3 of Table 1 . The DW statistics are now at 2.04 in the first equation and 1.98 in the second, which means that serial correlation has been almost entirely eliminated.

The Hansen test for the validity of over-identifying constraints suggests that the used instruments are valid as can be observed from the product of the J-statistic and the number of observations. 
Since our system is subject to five restrictions of the parameters, the resulting minimum distance measure (sum of squares) is larger than the unrestricted sum of squares (see Wooldridge, 2002: p. 201 and Greene, 2003: p.549). The overidentifying restrictions of the system are chi-square distributed with thirteen degrees of freedom (total count of instruments minus the number of coefficient to be estimated). Large values of this statistic imply the rejection of the null hypothesis (Baltagi, 2008: p. 270). Our J-statistic of 0.32 implying a value of $n J$ of about 7.5 is very low and thus an indication that the system overidentifying restrictions are significant. ${ }^{12}$

However, as Roodman (2007) cautions, this statistic may become downward biased as the instrument count increases and thereby fail to reject the null hypothesis. We therefore refine our estimation by successively allowing (i) a reduction in the instrument count to check how the Jstatistic reacts to these changes (Roodman 2007) and (ii) the automatic lag selection in the autocovariance matrix, adapted to the data sample size in order to increase the accuracy of the ttests (Newey and West, 1994). By allowing the automatic lag selection in our fourth regression, with a reduced instrument count, we obtain a high significance level for all of our coefficients with a sharp drop in the Hansen $\mathrm{J}$ - statistic from 0.32 to 0.10 . The fifth regression, which has two more instruments than the fourth, displays a slightly higher $\mathrm{J}$ statistic of 0.11 , which, in accordance with Roodman (2007), means that our instrument count does not bias the J statistic downwards and gives thus a confirmation of the validity of our instruments. ${ }^{13}$

\footnotetext{
${ }^{12}$ The probability that values of the chi-square distribution are below $n J=7.5$ is at the $10 \%$ level for the 13 degrees of freedom. As the Hansen test for the joint validity of instrument is also a test for the validity of the model specification, our J-statistic also suggests that the model specification is valid (Greene 2003; Roodman 2007; Baltagi 2008 ). All of the estimated coefficients except the one to be used for computing the rate of technical progress are also significant at $1 \%$ as indicated by their high t-values.

${ }_{13}$ The value for $n J$ is about 2.5 for these regressions. The probability that values of the chi-square distribution are below $n J=2.5$ is at the $1 \%$ level for 12 or 13 degrees of freedom.
} 


\subsection{Results}

We can thus use the above GMM results to compute the various elasticities according to the relationships indicated in the first column of table 1: we therefore use the results of the last regression to compute the elasticities, which can be interpreted with reasonable assurance. The labour product elasticity $\alpha$ is estimated at 0.66 , while the capital product elasticity $\beta$ is computed to be 0.36 . This regression yields thus coefficients that display minor increasing returns to scale as the sum of both factors' elasticity is slightly above 1 . The resulting income elasticity of export demand is now at about 2.86 while the estimation for export price elasticity yields (-1.6). These results produce an estimated rate of technical progress of about $1.38 \%$ per annum, which implies an annual rate of labour augmenting technical change of about $2 \%$ over the considered period, given the elasticity of labour productivity of 0.66 . This relatively strong ${ }^{14}$ rate of technical change reflects, as explained by Rodrik (2003), not only the gradual increase in technical efficiency, but also the advantage of allocative efficiency resulting from a sectoral shift from sugar to more valueadded industries in the export apparel and ICT sectors. It also reflects the increased utilisation of the human capital content of the labour force and the increasing technological content of imported machinery and equipment in the textile and ICT sector of the EPZ, where Mauritius deploys a more productive labour force and production technologies almost matching the world best practices (Wingnaraja, 2001). Indeed, the remarkably strong investment in human capital accumulation and the good quality of its bilingual (French and English) labour force have been crucial determinants of Mauritian industrial transformation.

\section{TABLE 1 OVER HERE}

\footnotetext{
14 In comparison, the OECD countries had an average of 1,7\% labour augmenting technical change over similar periods.
} 


\subsection{Steady-state growth rates, engine and handmaiden effects and dynamic gains from trade}

So far, we have estimated the model for its non-steady-state version. For long-run predictions, the theory gives us the steady-state formulas for growth rates of expected values. In this section, we calculate the steady-state growth rates of equations (10)-(12) numerically so as to specify the longrun predictions of the estimated models. We calculate the engine $(g)$ handmaiden $(m)$ and scale $(s)$ effects as defined below, in order to compare them to each other and in order to assess the effects of export growth rates on GDP per capita growth rates in the long run. Finally, we define and calculate the dynamic gains from trade as the difference between the predicted growth of the present model and that of the corresponding Solow model. The derivative of equation (12) with respect to $d \ln (Z)$ is the engine effect $g$, with respect to $b$ is the handmaiden effect $m$, and with respect to $d \ln (L)$ is the scale effect $s$ to the extent that it would drop out if there were constant returns to scale.

$$
\begin{aligned}
& g=\frac{\beta \rho}{\beta(\eta+1)-\eta} \\
& m=\frac{-\eta}{\beta(\eta+1)-\eta} \\
& s=\frac{-\eta(\alpha+\beta-1)}{\beta(\eta+1)-\eta}
\end{aligned}
$$

Next, $x$ represents the corresponding growth rate of the Solow model, assuming that its parameters are identical to those of our estimates.

$$
x=\frac{b+(\alpha+\beta-1) \varepsilon}{\beta(\eta+1)-\eta}
$$


Finally, the difference in the growth rates of our model according to equation (12), $d \ln (y)$, and the corresponding Solow model, denoted $t$, is defined as the dynamic steady-state gains from trade. ${ }^{15}$ $t=d \ln y-x$

In Table 2, we report the steady-state results for the growth rates of $k, p$ and $y$ as well as the engine, handmaiden and scale effects the Solow growth rate $x$, and the difference, $t$, of our model with the latter.

All calculations are done under the assumption that the driving trade partners income will continue to grow at $2.49 \%$. Finally, we need an assumption for the growth rate of employment. Our best estimate about employment growth is derived from the analysis of the employment behaviour in Mauritius in the past. Here, it is not superfluous to recall the adverse employment effects of the expiry of the MFA at the beginning of 2005. Indeed, the most direct effect of the dismantling of the MFA has been that a significant number of locally based large foreign textile firms, in particular those from Hong-Kong that have been supplying the US market from Mauritius have relocated to cheaper production location in Asia or elsewhere in Africa, leading to massive employment loss on the island (Lal and Peedoly, 2007). Over the 15 years preceding the MFA dismantling, employment growth has been positive but oscillating, averaging around $1.8 \%$ per annum as illustrated on figure 3 . We assume this rate to be maintained in the long run and use it for our steady state estimation besides alternative scenarios using values in the range of $0-5 \%$ for employment growth.

\section{FIGURE 3 OVER HERE}

We use the elasticities calculated in the last regression in Table 1 and find the following results: The steady-state growth rates of capital per worker are positive for all values of employment

\footnotetext{
${ }^{15}$ Small deviations from constant returns to scale have almost no effect on except for the scale effect which goes to zero under CRS.
} 
growth from $0-5 \%$. This rate of employment growth corresponds to per capita income steady state growth rate of about $2.35 \%$. For the assumed average employment growth of around $1.8 \%$, capital per worker grows at $4.49 \%$, while the steady-state per capita income grows at about $3 \%$. Lower values of steady state employment growth yield a better growth of capital stock per worker and thus a slightly better per capita income growth rate (respectively $5.4 \%$ and almost $3.4 \%$ if employment grows with $0.5 \%$ ). This is due to the relatively high income elasticity of export demand and the technical progress implied by $b=1.4 \%$. The presence of some scale effects, be they small, tends to reinforce the effects of technical change. The terms of trade will only fall if employment grows rapidly, i.e. above $4.5 \%$, and will evolve positively for values of employment growth below this rate.

In our Mauritian case, terms of trade growth remains positive because of the growth of the export demand, as illustrated by the income elasticity of 2.86 . For values where the supply effects of employment and technical change are larger than that of the demand force, trade partners income growth multiplied by the income elasticity, terms of trade will fall. For values of employment growth of $4.5 \%$ and below, demand side factors dominate and terms of trade will improve. The handmaiden effect of technical progress multiplied by the rate of technical change, $m^{*} b=0.016$, is smaller than the engine effect multiplied by the difference between trade partners' income growth rate and population growth rate, $g *(\rho d \ln (Z)-d \ln (L)) / \rho$ for lower values of employment growth and larger than the scale effect, $\left(s^{*} d \ln (L)\right)$ again because of the relatively high income elasticity of export demand and the relatively low measure of returns to scale. With lower labour employment growth, this engine effect becomes stronger than the handmaiden effect, while the scale effect gradually vanishes (see last two columns of Table 2).

\section{TABLE 2 OVER HERE}


The steady-state part of the dynamic gains from trade, $t$, is positive for the presented values of employment growth and increases with lower values of employment growth rates. As illustrated by Lewer and van den Berg (2003), dynamic gains from trade are large when export growth rates are high in the transition after taking policy measures. Therefore, static gains from trade and the gains during transition may be larger than those in the steady state.

\section{Conclusion}

The growth model outlined in this paper shows that the size of a country's income and price elasticities of export demand are an important determinants of its growth and development path, unless the price elasticity is minus infinity. According to our estimates, income elasticity of export demand is relatively high for Mauritius and the price elasticity is minus -1.6 and as a consequence, the engine-of-growth effects are strong as well. As the income elasticity here is high, foreign growth will be translated into more than proportional domestic export growth. A high income elasticity in combination with technical progress will lead to a positive evolution of terms of trade in the steady state, giving rise to a relaxation of the balance of payments constraint.

In particular, given the estimated income demand elasticity of 2.86 , the steady state engine effects will be positive for employment growth rates below 5\% and will remain important for the assumed foreign income growth rate and the average employment growth rate of $1.8 \%$. At this rate of employment growth, the positive engine effects will lead to gradual catching up. Engine effects are thus very important because long-run per capita income growth may be larger than the sum of the rate of technical change the rate of increasing returns to scale. The effect of increasing returns is to act in favour of higher growth in this case and employment growth works in the same direction as technical progress but this effect is very low for Mauritius. 
The model allows for positive growth rates of the terms and trade and per capita income through imported capital goods, positive dynamic gains from trade and increasing returns. According to our estimates, the income elasticity is relatively large, and if Mauritius continues to take advantage of the preferential access to the US textile markets through the Africa Growth and Opportunities Act (AGOA), this may mean a growth engine without driving down the terms of trade, in line with the expectations. However, the effect may become weakened due to a relatively high price elasticity of export demand, which can translate the positive evolution of terms of trade into a lower export demand. This relatively high price elasticity can be traced to Mauritius' strategy of positioning itself at the differentiated high end of the textile, apparel and tourism sectors. Both arguments interact and are quantitatively relevant. According to our model, neither of the two can be dismissed because technical change matters on the supply side and exports are important determinants on the demand side.

Finally, as the literature on devaluations emphasizes the effects of devaluations for explaining the terms of trade movements, our finding of a price elasticity of about -1.6 implies that devaluations inducing a real fall in export prices would be followed by higher growth rates, since nominal devaluations have real effects (Bahmani-Oskooee and Miteza, 2002).

The steady-state part of dynamic gains from international trade is also dependent on the level of employment growth: high employment growth could yield negative dynamic gains from trade in the steady state, whereas low employment growth brings about positive gains from trade. The impact of employment growth on steady-state output growth is less negative under increasing returns than under constant returns. Moreover, due to the relatively high price elasticity, steadystate growth will not be hampered by employment when its growth does not exceed its values of the past. It is obvious that price movements matter for the value of exports: the current results 
clearly demonstrate that income and price elasticities of export demand may be important explanations for the growth of Mauritius in the examined period.

As labour force growth slows down, increasing dynamic gains from trade can be generated by trade partners income growth, which translates into higher demand for exports and thus in higher domestic growth for Mauritius. Given the current conjuncture that forces Mauritius to seek other strategic growth sectors than textile, it is obvious that continued dynamic gains from the current trade patterns could translate into linkages supporting other production technologies, which will also affect the values of export demand and price elasticities in the future, and thereby codetermine the new growth prospects of the island. 


\section{References}

Bahmani-Oskooee, M. and M. Miteza (2002) Do nominal devaluations lead to real devaluations in LDCs? Economics Letters, 74, 385-391.

Balassa, B. (1978) Exports and economic growth: Further evidence. Journal of Development Economics, 5 (2), 181-89.

Balassa, B. (1985) Exports, policy choices, and economic growth in developing countries after the 1973 oil shock. Journal of Development Economics, 4 (1), 23-35.

Baltagi, B. (2008) Econometrics, $4^{\text {th }}$ edition. Springer-Verlag, Berlin Heidelberg.

Bardhan, P. and S. Lewis (1970) Models of Growth with Imported Inputs. Economica, November 373-358.

Bernard, A. and J. Jensen (1999) Exporting and Productivity. NBER Working Paper 7135, Cambridge, MA.

Bértola, L., H. Higachi and G. Porcile (2002) Balance-of-payments-constrained growth in Brazil: a test of Thirlwall's Law, 1890-1973. Journal of Post-Keynesian Economics, 25 (1), 123140.

Bhagwati, J. (1978) Anatomy and Consequences of Exchange Control Regimes: Liberalization Attempts and Consequences. Cambridge, MA: Ballinger.

Caselli, F. and D. Wilson (2004) Importing Technology. Journal of Monetary Economics, 51 (1), 1-32.

Davidson, R. and J. MacKinnon (2004) Econometric Theory and Methods. Oxford University Press.

Eaton, J. and S. Kortum (2001). Trade in Capital Goods. European Economic Review, 45 (7), 1195-1235.

Esfahani, H. (1991) Exports, imports, and economic growth in semi-industrialized countries. Journal of Development Economics, 35, 93-116.

Fagerberg, J. (1988) International Competitiveness. Economic Journal, 98, 355- 374.

Greene, W. (2003) Econometric Analysis, fifth edition, Prentice Hall International, Inc.

Heston, A., R. Summers and B. Aten (2006) Penn World Table Version 6.2, Center for International Comparisons of Production, Income and Prices at the University of Pennsylvania, September 2006. 
Keller, W. (2002) Trade and the Transmission of Technology, Journal of Economic Growth, 7, 496-51.

Khan, M. and M. Knight (1988) Import Compression and Export Performance in Developing Countries. Review of Economics and Statistics, 70 (2), 315-321.

Kravis, I. (1970) Trade as a Handmaiden of Growth. Economic Journal, December, 850-872.

Lal, K. and A. S. Peedoly (2007) Textiles \& Clothing Industry and Economic Development: A Global Perspective: A Case Study of Mauritius. UNU-MERIT Working Paper Series.

Lamusse, R. (1980) Labour Policy in Plantation Islands. World Development, 8 (12), 1035-1050.

Lee, Jong-Wha (1995) Capital goods imports and long-run growth. Journal of Development Economics, 48 (1), 91-110.

Lewer, J. and H. van den Berg (2003) How Large is International Trade's Effect on Economic Growth. Journal of Economic Surveys, 17 (3), 363-396.

Marwah, K and L. Klein (1998) Economic Growth and Productivity Gains from Capital Inflow: Some Evidence for India. Journal of Quantitative Economics, 14 (1), 81-108.

Mauritian Research Council (2006) Manufacturing Technology. MRC Publications

Mazumdar, J. (1999) Imported Machinery and growth in LDC. Journal of Development Economics, 65(1), 209-224.

Medina-Smith, E. (2001) Is the Export-Led Growth Hypothesis Valid for Developing Countries?

A Case Study of Costa Rica. Policy Issues in International Trade and Commodities Studies Series no 7 UNCTAD, Geneva and New York.

Mutz, C. and T. Ziesemer (2008) Simultaneous Estimation of Income and Price Elasticities of Export Demand, Scale Economies and Total Factor Productivity Growth for Brazil. Applied Economics, 40 (22), 2921 - 2937.

Navaretti, G. Barba. and I. Soloaga (2001) Weightless Machines and Costless Knowledge: An Empirical Analysis of Trade and Technology Diffusion. The World Bank, Washington DC

Newey, W. and K. West (1994) Automatic Lag Selection in Covariance Matrix Estimation. Review of Economic Studies, 61, 631-653.

Rodrigues, F. and D. Rodrik (1999) Trade Policy and Economic Growth: A Skeptic's Guide to the Cross-National Evidence. NBER Working Paper 7081, Cambridge, MA.

Rodrik, D. (2003) Introduction in: Rodrik, D.(ed). In Search of Prosperity. Princeton University Press, p. 4. 
Roodman, D. (2007) A Short Note on the Theme of Too Many Instruments. Center for Global Development Working Paper Nr. 125.

Solow, R. (1956) A Contribution to the Theory of Economic Growth. Quarterly Journal of Economics, 70 (1), 65-94.

Subramanian, A. and D. Roy (2003) Who Can Explain the Mauritian Miracle? Meade, Romer, Sachs or Rodrik? In: Rodrik, D.(ed) In Search of Prosperity. Princeton University Press: pp. 205-243.

Thangavelu, S. and G. Rajaguru (2004) Is there an export or import-led productivity growth in rapidly developing Asian countries? A multivariate VAR analysis. Applied Economics, 36, 1083-1093.

Verbeek, M. (2004) A Guide to Modern Econometrics, second edition. John Wiley \& Sons, Chichester.

Verspagen, B. (1993) Uneven Growth between Interdependent Economies, Avebury, Aldershot.

Wacziarg, R. (2001) Measuring the dynamic gains from Trade. World Bank Economic Review, 15, 393-429.

Wignaraja, G. (2001) Firm size, Technological Capabilities and Market-Oriented Policies in Mauritius. UNU-INTECH Discussion Paper Series.

Wingnaraja, G., M. Lezama and D. Joiner (2004) Small States in Transition: From Vulnerability to Competitiveness. The Commonwealth Secretariat.

Wooldridge J. (2002) Econometric Analysis of Time Series and Panel Data. MIT Press.

World Bank (2007) World Development Indicators. Washington D.C.

World Bank (1993) The East Asian Miracle. World Bank Publications, Washington D.C.

World Factbook 2006. CIA Publications, Washington D.C.

Ziesemer, T. (1995) Economic Development and Endogenous Terms-of-Trade Determination: Review and Reinterpretation of the Prebisch-Singer Thesis. UNCTAD Review, 17-33.

\footnotetext{
*We are grateful to Théophile Azomahou, Pierre Mohnen, Wladimir Raymond, Eddy Szirmai and Bart Verspagen for valuable discussions and useful suggestions. We remain however solely responsible for the content of this paper and all eventual errors and omissions.
} 


\begin{tabular}{|c|c|c|c|c|c|c|c|c|c|c|c|}
\hline \multirow[b]{2}{*}{ Variable } & \multirow{2}{*}{$\begin{array}{l}\text { Method } \\
\text { Coefficient(standard error) }\end{array}$} & \multicolumn{2}{|c|}{ Regr.1: OLS } & \multicolumn{2}{|c|}{ Regr.2: SUR } & \multicolumn{2}{|c|}{$\begin{array}{l}\text { Regr. } 3^{*} \text { : } \\
\text { GMM-HAC, } \\
\text { fixed N-W } \\
\text { bandwidth }\end{array}$} & \multicolumn{2}{|c|}{$\begin{array}{c}\text { Regr } 4^{\star *}: \\
\text { GMM-HAC, } \\
\text { variable N- } \\
\text { W } \\
\text { bandwidth, } \\
\text { fewer } \\
\text { instruments }\end{array}$} & \multicolumn{2}{|c|}{$\begin{array}{l}\text { Regr. } 5^{\star \star \star}: \\
\text { GMM HAC } \\
\text { with var N- } \\
\text { W same } \\
\text { instruments } \\
\text { count as } \\
\text { no3 }\end{array}$} \\
\hline & & Coeff & $\begin{array}{l}\text { Std } \\
\text { errors }\end{array}$ & Coeff & $\begin{array}{r}\text { Std } \\
\text { errors }\end{array}$ & Coeff & $\begin{array}{r}\text { Std } \\
\text { errors }\end{array}$ & Coeff & $\begin{array}{r}\text { Std } \\
\text { errors }\end{array}$ & Coeff & $\begin{array}{r}\text { Std } \\
\text { errors }\end{array}$ \\
\hline constant & $c(1)$ & -21.6977 & 6.5642 & 21.0429 & 4.7357 & 24.9349 & 3.3140 & 29.6799 & 1.2419 & 25.5733 & 1.7984 \\
\hline constant & $c(7)$ & -32.5373 & 12.0545 & 18.8442 & 6.9819 & 32.5153 & 4.7230 & 36.2549 & 1.5755 & 33.6205 & 2.9583 \\
\hline Lns & $c(2)=(\eta+1) / \eta$ & 0.4355 & 0.1286 & 0.5926 & 0.0818 & 0.3911 & 0.0607 & 0.3146 & 0.0178 & 0.3766 & 0.0360 \\
\hline $\mathrm{T}$ & $c(3)=b^{*}(\eta+1) / \eta$ & 0.0102 & 0.0105 & -0.0036 & 0.0138 & 0.0050 & 0.0044 & 0.0033 & 0.0015 & 0.0053 & 0.0021 \\
\hline $\operatorname{lnK}(-1)$ & $c(4)=\left(\beta^{*} \eta+\beta-\eta\right) / \eta$ & -0.8821 & 0.2516 & -0.5094 & 0.3048 & -0.8484 & 0.0902 & -0.8637 & 0.0283 & -0.8624 & 0.0485 \\
\hline $\ln (\mathrm{L})$ & $c(5)=a^{*}(n+1) / \eta$ & 0.2714 & 0.0859 & 0.3206 & 0.0647 & 0.2566 & 0.0331 & 0.2041 & 0.0135 & 0.2497 & 0.0197 \\
\hline $\ln Z$ & $c(6)=-p / \eta$ & 1.6396 & 0.3657 & 1.2093 & 0.2393 & 1.7449 & 0.1722 & 1.9796 & 0.0526 & 1.7881 & 0.1043 \\
\hline $\ln \left(K^{\wedge}+\delta\right)(-1)$ & $c(8)$ & 0.8705 & 0.1059 & 0.9636 & 0.1267 & 0.8025 & 0.0616 & 0.8587 & 0.0325 & 0.8096 & 0.0331 \\
\hline $\operatorname{lnp}(-1)$ & $c(9)$ & 1.0844 & 0.2311 & 0.9051 & 0.1294 & 1.0953 & 0.0877 & 1.1092 & 0.0350 & 1.1053 & 0.0533 \\
\hline $\operatorname{lnp}(-2)$ & $c(10)$ & -0.4058 & 0.1155 & -0.5315 & 0.1272 & -0.3299 & 0.0657 & -0.3613 & 0.0354 & -0.3374 & 0.0333 \\
\hline \multicolumn{12}{|c|}{ implied elasticities } \\
\hline \multicolumn{2}{|c|}{ labour prod. elasticity a } & 0.6232 & & 0.5410 & & 0.6562 & & 0.6487 & & 0.6632 & \\
\hline \multicolumn{2}{|c|}{ Capital prod elasticity $\beta$} & 0.2708 & & 0.8279 & & 0.3876 & & 0.4334 & & 0.3654 & \\
\hline \multirow{2}{*}{\multicolumn{2}{|c|}{$\begin{array}{l}\text { tip growth b } \\
\text { Export income elasticityp }\end{array}$}} & 0.0235 & & -0.0061 & & 0.0127 & & 0.0106 & & 0.0140 & \\
\hline & & $\begin{array}{r}2.9044 \\
-1.7714\end{array}$ & & $\begin{array}{r}2.9683 \\
-24546\end{array}$ & & $\begin{array}{r}2.8656 \\
-16422\end{array}$ & & $\begin{array}{r}2.8882 \\
-14590\end{array}$ & & $\begin{array}{r}2.8681 \\
-16040\end{array}$ & \\
\hline \multicolumn{2}{|c|}{ Export price elasticity $\eta$} & $\begin{aligned}-1.7714 \\
5.1 \mathrm{E}_{+}\end{aligned}$ & & $\begin{array}{r}-2.4546 \\
1.11 E_{-1}\end{array}$ & & $\begin{array}{l}-1.6422 \\
1959.41\end{array}$ & & $\begin{array}{r}-1.4590 \\
716.888\end{array}$ & & $\begin{array}{l}-1.6040 \\
3124.90\end{array}$ & \\
\hline \multicolumn{2}{|c|}{ Initial productiv level A } & & & & & & & & & 76 & \\
\hline B & & $4.75 E-21$ & & $4.75 E-21$ & & $1.26 \mathrm{E}-20$ & & $7.64 \mathrm{E}_{-21}$ & & $1.18^{E-20}$ & \\
\hline regression fit & & eq1 & & eq1 & Eq2 & eq1 & eq2 & eq1 & eq2 & eq1 & eq2 \\
\hline R-sq & & 0.96303 & 0.8606 & 0.9574 & 0.8993 & 0.9112 & 0.7583 & 0.9409 & 0.7231 & 0.9118 & 0.7505 \\
\hline Adj R-sq & & 0.947807 & 0.8165 & 0.9399 & 0.8675 & 0.8668 & 0.6676 & 0.9133 & 0.6192 & 0.8677 & 0.6569 \\
\hline D-W stat & & 2.177045 & 1.9281 & 2.1739 & 2.0083 & 2.0434 & 1.9815 & 2.2318 & 1.8840 & 2.07972 & 1.9669 \\
\hline J-statistic & & & & & & 0.3211 & 0.3211 & 0.1096 & 0.1096 & 0.1145 & 0.1145 \\
\hline \multirow{2}{*}{\multicolumn{2}{|c|}{ Number of observations }} & 25 & 26 & 23 & & 22 & 23 & 23 & 23 & 22 & 23 \\
\hline & & & & & & 7.0652 & 7.3864 & 2.5208 & 2.5208 & 2.5191 & 2.6335 \\
\hline
\end{tabular}

- $\quad{ }^{*}$ Fixed N-W bandwidth. 23 instruments: equation 1 : c, $\operatorname{lns}(-1), \mathrm{t}, \ln \mathrm{K}(-1), \ln \mathrm{K}(-2) \ln \mathrm{K}(-3) \ln \mathrm{K}(-4) \ln \mathrm{K}(-5), \ln (\mathrm{L}), \ln \mathrm{Z} \ln \left(\mathrm{K}^{\wedge}+\delta\right)(-1)$ and $\ln \left(\mathrm{K}^{\wedge}+\delta\right)(-2)$. Equation 2: c, $\operatorname{lns}(-1), \mathrm{t}, \ln \mathrm{K}(-2), \ln \mathrm{K}(-3), \operatorname{lnk}(-4), \ln (\mathrm{L}), \ln \mathrm{Z}, \ln \mathrm{p}(-1)$ and $\operatorname{lnp}(-2) \ln (-3)$

- $\quad{ }^{* *}$ Variable N-W bandwidth.. 21 instruments: equation $1: \mathrm{c}, \ln s(-1), \mathrm{t} \ln \mathrm{K}(-2), \ln \mathrm{K}(-3),, \ln \mathrm{K}(-4) \ln (\mathrm{L}), \ln \mathrm{Z}$ and $\ln \left(\mathrm{K}^{\wedge}+\delta\right)(-1)$ to $\ln \left(\mathrm{K}^{\wedge}+\delta\right)(-$ 2). Eq. 2: c, $\operatorname{lns}(-1), t, \ln \mathrm{K}(-1), \ln \mathrm{K}(-2), \operatorname{lnk}(-3), \operatorname{lnk}(-4), \ln (\mathrm{L}), \ln \mathrm{Z} \ln (-2)$ and $\operatorname{lnp}(-3)$

- $\quad{ }^{* * *}$ Variable N-W bandwidth. 22 instruments: equation 1 : c, $\operatorname{lns}, \mathrm{t}, \ln \mathrm{K}(-2), \ln \mathrm{K}(-3), \ln \mathrm{K}(-4), \ln \mathrm{K}(-5) \ln (\mathrm{L}), \ln \mathrm{Z} \ln \left(\mathrm{K}^{\wedge}+\delta\right)(-2)$ and $\ln \left(\mathrm{K}^{\wedge}+\delta\right)(-3)$. Eq. $2: \mathrm{c}, \operatorname{lns}, \mathrm{t}, \ln \mathrm{K}(-2), \operatorname{lnk}(-3), \ln \mathrm{K}(-4) \ln (\mathrm{L}), \ln \mathrm{Z}, \operatorname{lnp}(-1) \operatorname{lnp}(-2)$ and $\operatorname{lnp}(-3)$ 
Table 2: Steady state engine, handmaiden and scale effects for alternative employment growth rates

\begin{tabular}{lrrrrrrrrr}
\hline $\begin{array}{l}\text { Assumed employment } \\
\text { growth }\end{array}$ & $5 \%$ & $4,5 \%$ & $4 \%$ & $2 \%$ & $1,8 \%$ & $1,5 \%$ & $1 \%$ & $0,5 \%$ & 0 \\
\hline Capital growth & 0.0221 & 0.0257 & 0.0292 & 0.0434 & 0.0449 & 0.0470 & 0.0506 & 0.0541 & 0.0577 \\
DInp & -0.0013 & 0.0011 & 0.0035 & 0.0130 & 0.0140 & 0.0154 & 0.0178 & 0.0202 & 0.0226 \\
DIny & 0.0235 & 0.0246 & 0.0258 & 0.0304 & 0.0309 & 0.0316 & 0.0327 & 0.0339 & 0.0350 \\
G & 0.7577 & 0.7577 & 0.7577 & 0.7577 & 0.7577 & 0.7577 & 0.7577 & 0.7577 & 0.7577 \\
$\mathrm{M}$ & 1.1596 & 1.1596 & 1.1596 & 1.1596 & 1.1596 & 1.1596 & 1.1596 & 1.1596 & 1.1596 \\
$\mathrm{~S}$ & 0.0332 & 0.0332 & 0.0332 & 0.0332 & 0.0332 & 0.0332 & 0.0332 & 0.0332 & 0.0332 \\
$\mathrm{X}$ & 0.0111 & 0.0110 & 0.0109 & 0.0105 & 0.0105 & 0.0104 & 0.0103 & 0.0102 & 0.0101 \\
$\mathrm{~T}$ & 0.0124 & 0.0136 & 0.0149 & 0.0199 & 0.0204 & 0.0212 & 0.0224 & 0.0237 & 0.0249 \\
$\mathrm{~g}^{*}\left(e^{*} \ln (\mathrm{Z})-\mathrm{d} \ln (\mathrm{L})\right) / \mathrm{P}$ & 0.0162 & 0.0199 & 0.0237 & 0.0389 & 0.0404 & 0.0427 & 0.0465 & 0.0503 & 0.0540 \\
$\mathrm{~m}^{*} \mathrm{~b}$ & 0.0162 & 0.0162 & 0.0162 & 0.0162 & 0.0162 & 0.0162 & 0.0162 & 0.0162 & 0.0162 \\
$\mathrm{~S}^{*} \mathrm{~d} \ln (\mathrm{L})$ & 0.0017 & 0.0015 & 0.0013 & 0.0007 & 0.0006 & 0.0005 & 0.0003 & 0.0002 & 0.0000 \\
$\mathrm{dlnZ}$ & 0.0249 & 0.0249 & 0.0249 & 0.0249 & 0.0249 & 0.0249 & 0.0249 & 0.0249 & 0.0249 \\
& & & & & & & & & \\
$\mathrm{~B}$ & 0.0140 & 0.0140 & 0.0140 & 0.0140 & 0.0140 & 0.0140 & 0.0140 & 0.0140 & 0.0140 \\
Beta & 0.3654 & 0.3654 & 0.3654 & 0.3654 & 0.3654 & 0.3654 & 0.3654 & 0.3654 & 0.3654 \\
Eta & -1.6040 & -1.6040 & -1.6040 & -1.6040 & -1.6040 & -1.6040 & -1.6040 & -1.6040 & -1.6040 \\
Alpha & 0.6632 & 0.6632 & 0.6632 & 0.6632 & 0.6632 & 0.6632 & 0.6632 & 0.6632 & 0.6632 \\
\hline Rho & 2.8681 & 2.8681 & 2.8681 & 2.8681 & 2.8681 & 2.8681 & 2.8681 & 2.8681 & 2.8681 \\
\hline
\end{tabular}




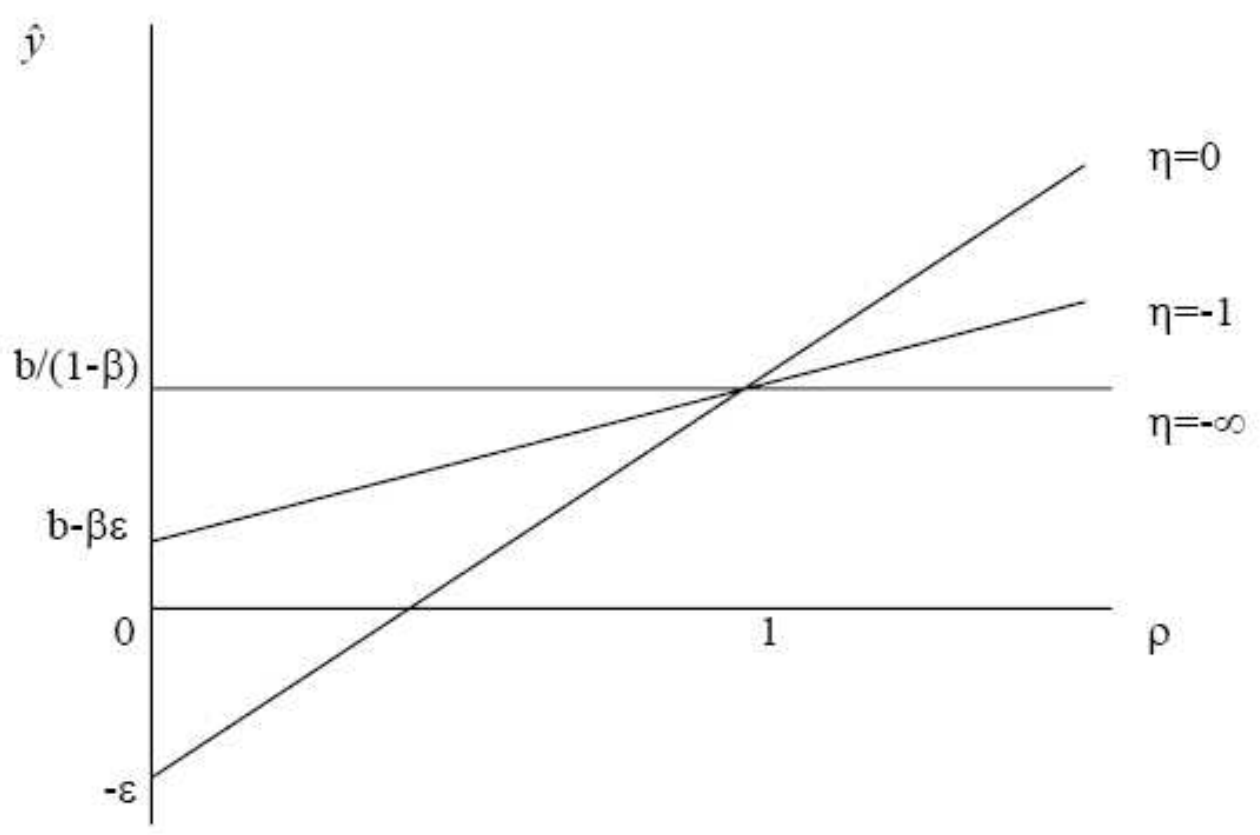

Figure 1: Relationship between output growth rate and the export demand income elasticity for different values of price elasticity 


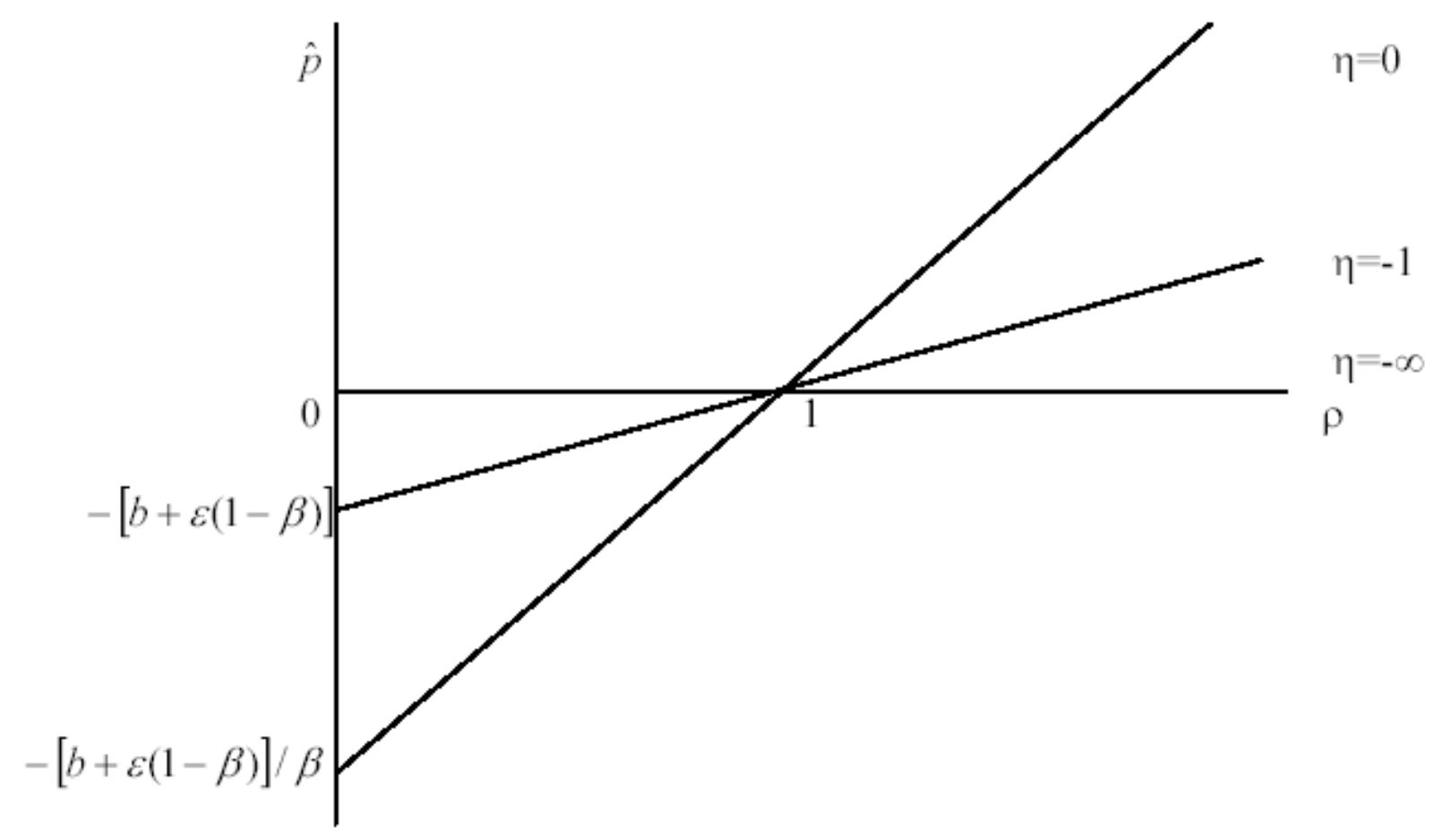

Figure 2. Relationship between growth rate of terms of trade and the export demand income elasticity for different values of price elasticity 
Figure 3: Mauritian employment growth 1989-2005

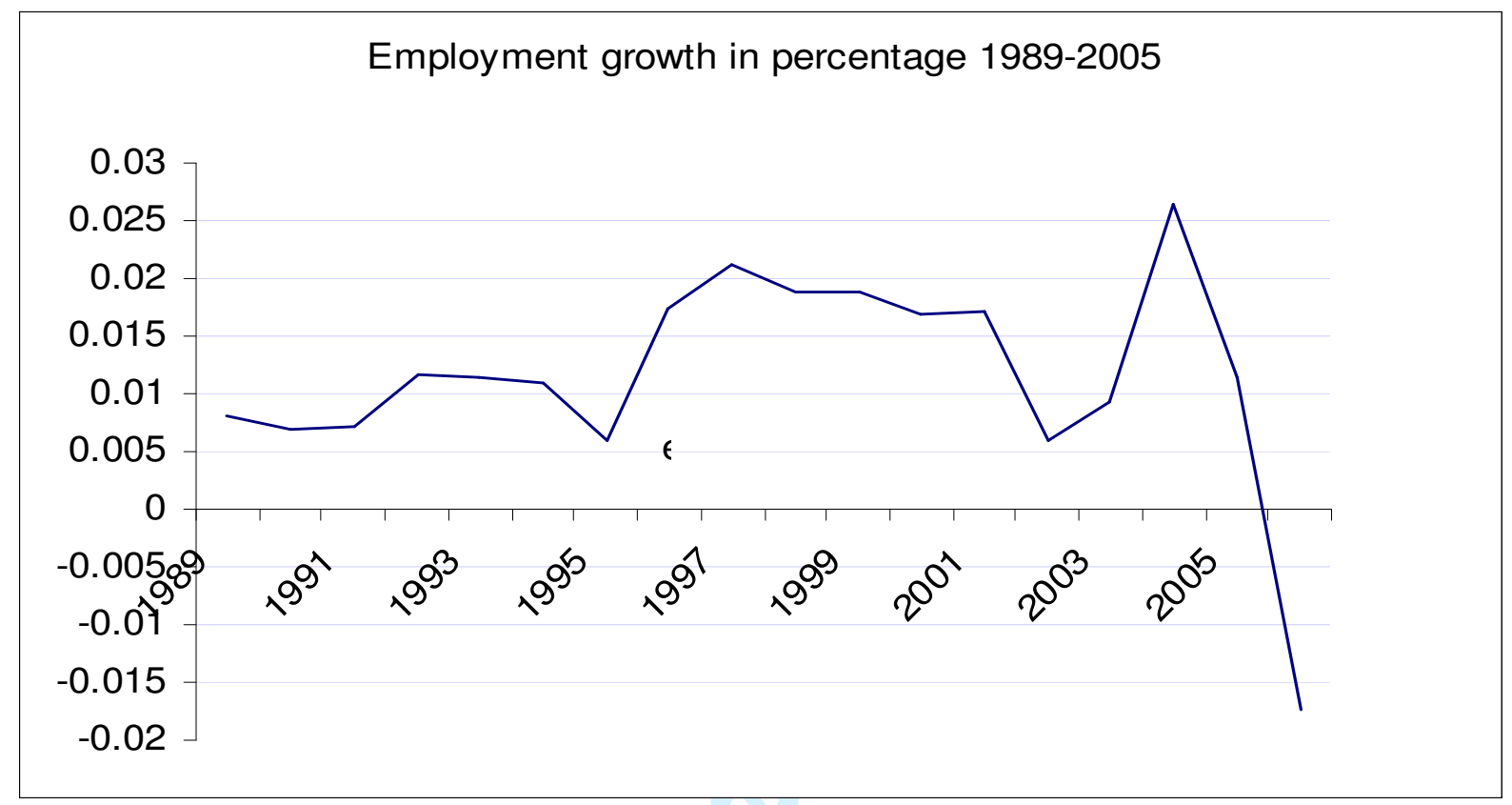

Graph plotted with CSO data 